E3S Web of Conferences 1, 19001 (2013)

DOI: $10.1051 / \mathrm{e} 3 \operatorname{sconf} / 20130119001$

(C) Owned by the authors, published by EDP Sciences, 2013

\title{
Soil Contamination at the Historical Zn-Pb Ore Mining Sites (Southern Poland)
}

\author{
$\underline{\text { U. Aleksander-Kwaterczak }}^{1}$ and D. Ciszewski \\ ${ }^{1}$ AGH University of Science and Technology, Krakow, Poland, aleksa@geol.agh.edu.pl
}

\begin{abstract}
Results of metals analyses in soil profiles sampled at two $18 / 19^{\text {th }}$ century mine shafts of the Trzebinia lead-zinc ore mining region in southern Poland are presented. Waste dump sites located at these shafts exhibit initial pedogenesis with clear differences in zinc and cadmium content between soil horizons which changes in depth across each of the investigated dump. The highest metal concentrations occur in horizons containing excavated ore-bearing Triassic dolomites, soils buried beneath are less polluted whereas, initial A0 soil horizons are virtually unpolluted. Relatively low downward metal migration in profiles to the horizons underlying the dumps is related to alkaline $\mathrm{pH}$ of soils. Migration appear to be important in the more acidic soils of outer zones in the two dump sites overgrown either with coniferous and deciduous trees.
\end{abstract}

Keywords: Heavy metals, soils, contamination, historical mining area

\section{Introduction}

The lead-zinc ore mining in Lgota at Trzebinia region in southern Poland is known since Middle ages however, the most intensive exploitation took place at the break of $18^{\text {th }}$ and in the $19^{\text {th }}$ century. Exploitation introduced far-reaching geomorphological changes to the environment because of numerous shallow shafts accompanied by several-meters high dumps of waste material surrounding each shaft. At present, old shafts form holes several meters deep and several tens of meters in diameter with a distinct bunding of rock overburden. About 400 of these forms in Lgota occupy the forested area of approximately $8 \mathrm{~km}^{2}$. The paper describes variability of zinc and cadmium concentrations in soil profiles sampled from two dumps in this area.

\section{Materials and Methods}

Soil profiles were sampled at two sites overgrown with deciduous (beach dominated) and coniferous (pine dominated) forest. At each, the $3 \mathrm{~m}$ high dump, three soil profiles were digged with a spade (Fig. 1). Profiles were localized at the highest point of the dump, on the dump escarpment and at the foot of the dump. The height of profiles varied between 2.8 and $0.5 \mathrm{~m}$.

Profiles were divided into sections according to their lithology. In the obtained samples, bulk density, potential and active $\mathrm{pH}$, water content, organic matter content and carbonate by weight, grain diameter, total metals content $(\mathrm{Cd}, \mathrm{Pb}, \mathrm{Cu}, \mathrm{Fe}, \mathrm{Mn}$ and $\mathrm{Zn})$ by means of AAS method and also chemical forms of their occurrence (BCR method) were determined.

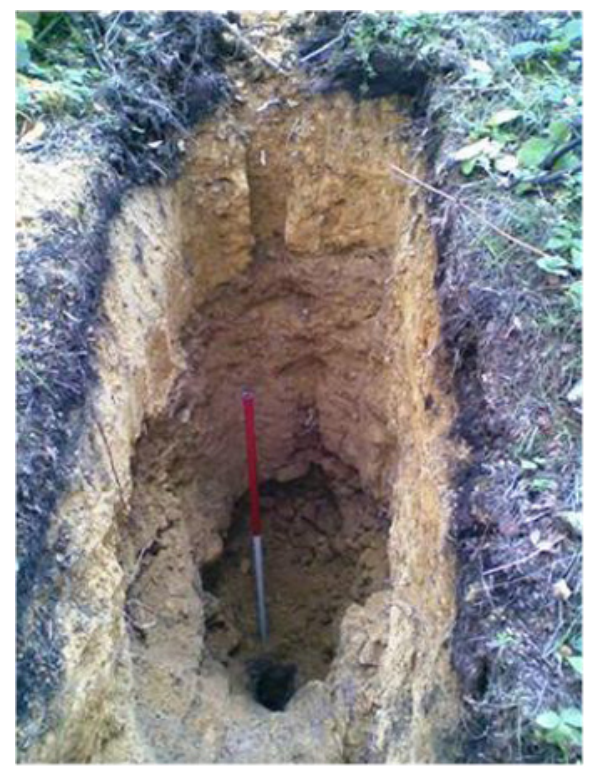

Fig.1 Soil profile in the Lgota region

\section{Results and Discussion}

At both sampling sites considerable variation of the investigated parameters is correlated to lithology. In the 
beech forest active $\mathrm{pH}$ values range from 6.15 in the $\mathrm{A} 0$ horizon to 9.20 in the ore-bearing dolomite material and decreases again in the buried A0 horizon (8.41). Organic matter content generally follows the same distribution pattern and decreases from $75.3 \%$ at the surface to $0.20 \%$ in the dolomite wastes, while carbonates content rise from 1.57 at the surface to $93.3 \%$ in the underlying layer and decrease again to $2.34 \%$ in the bottom organic horizon.

In the coniferous forest active $\mathrm{pH}$ range from 6.00 in the initial A0 horizon to 8.72 in the dolomitic wastes, whereas organic matter changes from $93.3 \%$ at the surface to a total disappearance beneath, with reversed trend in carbonates content which vary from 0.13 to $96.5 \%$.

In the analyzed soils zinc and cadmium concentrations vary between 119.3-31 816 and 1.7-741.9 $\mathrm{mg} / \mathrm{kg}$, respectively. Despite high $\mathrm{pH}$ of the dolomitic waste material, buried A0 soil horizons are evidently enriched in zinc and cadmium as a result of leaching of the overlying material. The effect seems to be relatively small in the longest profiles where only about dozen or so $\mathrm{cm}$ layer is polluted to the $50 \%$ of the metal content in the overlying wastes or cadmium and zinc content does not exceed $20 \%$ of that in the wastes. The effect seems to be larger in short profiles, if compared to thickness of the mining wastes. In profiles taken at the foot of the heaps, with the waste layer only few $\mathrm{cm}$ thick, raised cadmium and zinc content occurs to the depth over $30 \mathrm{~cm}$ and may be related to more effective leaching in more acidic conditions. This may be supported by the particularly high, up to $100 \%$, content of cadmium in the most mobile fraction in the buried soils of the coniferous forest and overall increase of cadmium mobility down the investigated profiles. This regularity is not observed in case of the $2.8 \mathrm{~m}$-long profile because the bottom layers were not affected by cadmium migration. Generally, considering relatively short period of time and good buffer soil properties, metal migration seems to be large rather in term of concentrations than any particular depths (Abollino et al. 2002, Sterckeman et al. 2000, Maskall et al. 1996).

\section{Conclusions}

The investigations indicate oversized metal concentrations in the analyzed soil profiles. A large percentage of these metals in the potentially mobile forms and enrichment of buried soil horizons suggest that large part of cadmium and much less of zinc migrate downward by a depth several tens of centimeters over about 200 years. It seems to be related to acidification of soils particularly of the coniferous forest due to fulvic acids content. However, metal migration in profiles is mitigated by high $\mathrm{pH}$ of the waste material and the good buffer properties of soils, encroachment of forest communities over the contaminated waste heaps may affect mobility of at least the most mobile elements.

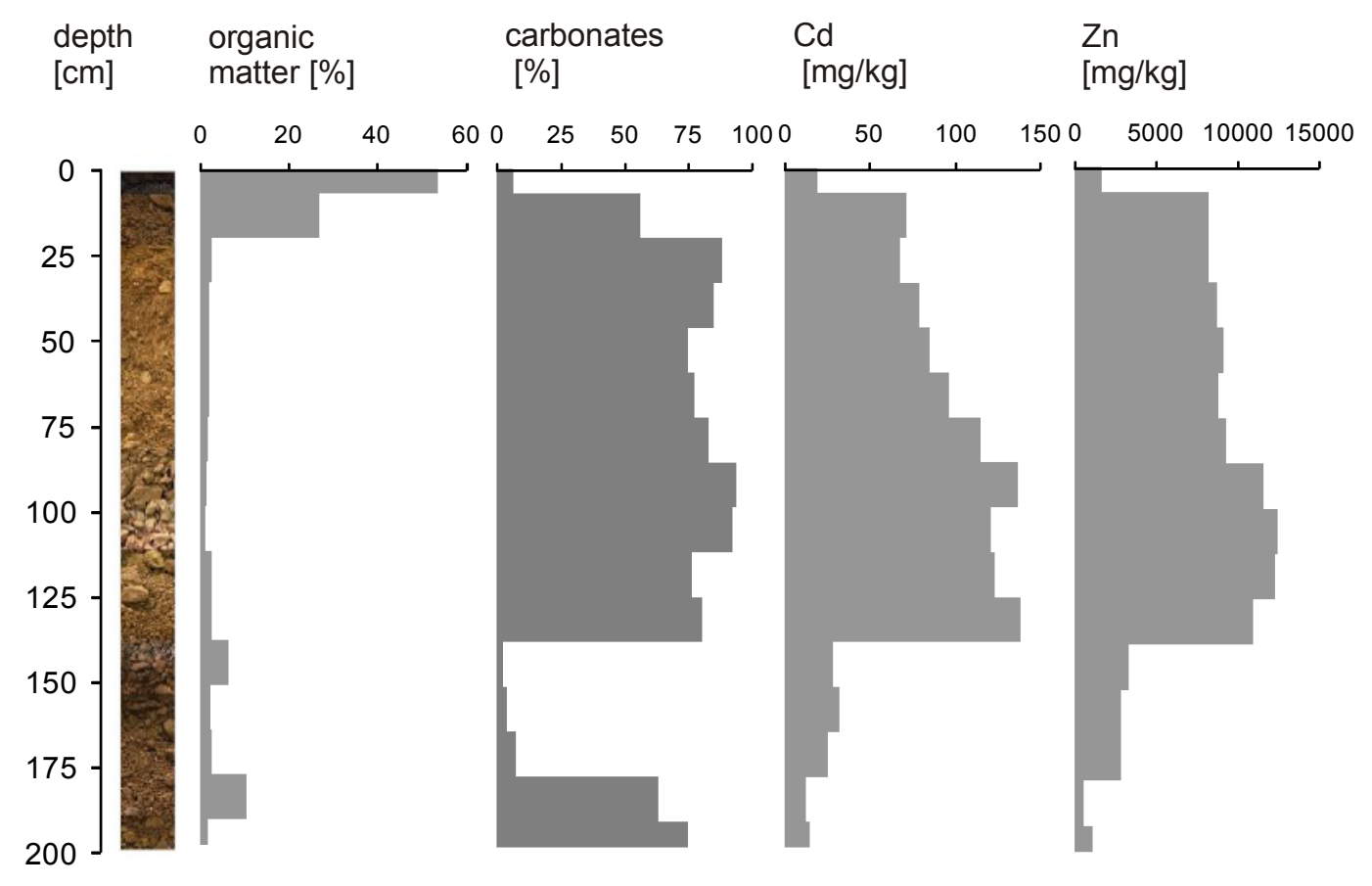

Fig.2 Distribution of organic matter, carbonates, cadmium and zinc in the soil profile from deciduous forest 


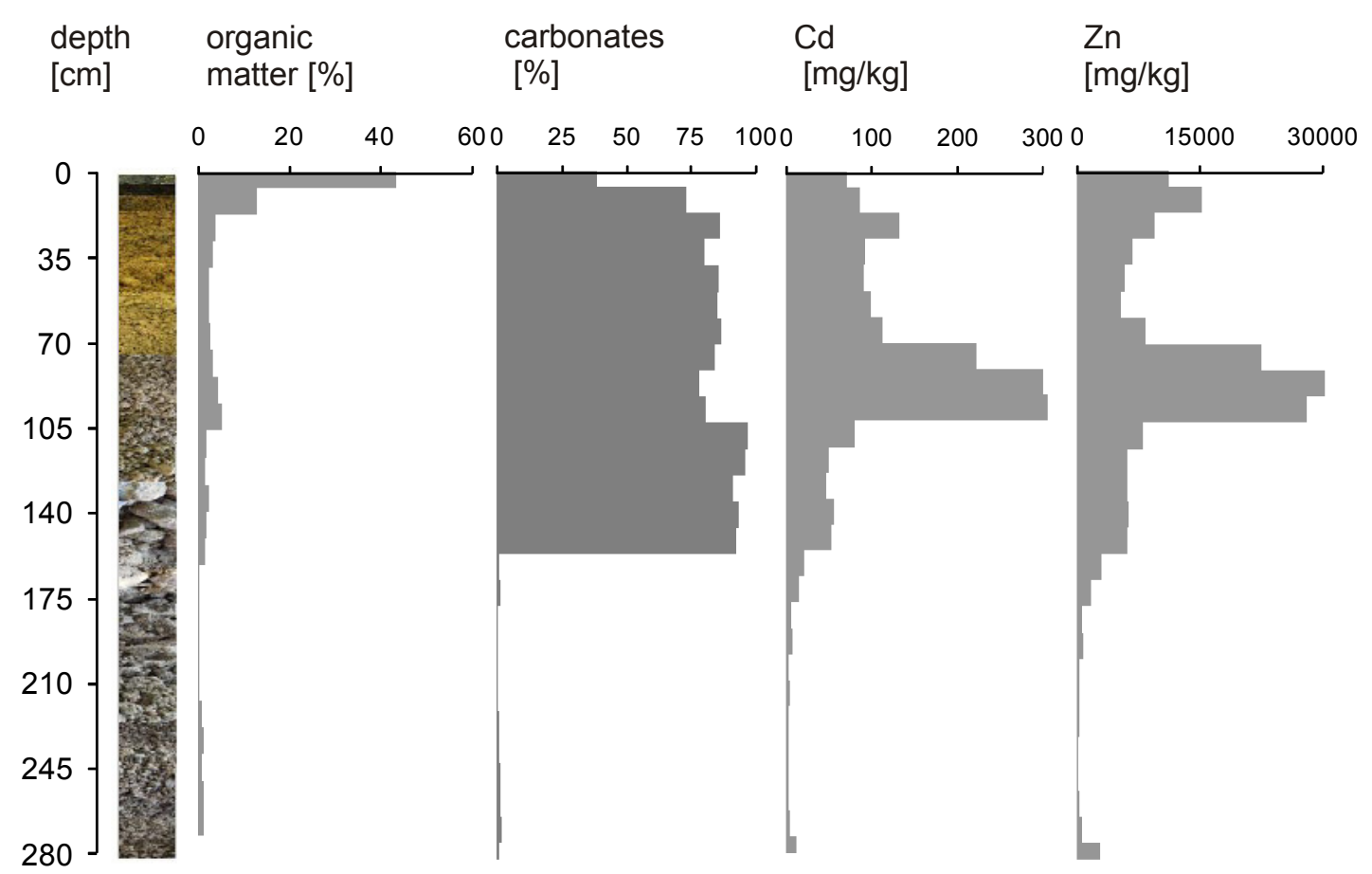

Fig.3 Distribution of organic matter, carbonates, cadmium and zinc in the soil profile from coniferous forest

\section{Acknowledgements}

The authors thank to the financial supports providing from Project of Statutory Research of Geology, Geophysics and Environment Department of AGH University.

\section{References}

Abollino O., Aceto M., Malandrino M., Mentasti E., Sarzanini C., Barberis R., Distribution and mobility of metals in contaminated sites. Chemometric investigation of pollutant profiles. Environmental Pollution 2002; 119:177-193.

Maskall J., Whitehead K., Gee C., Thornton I., Long-term migration of metals at historical smelting sites. Applied Geochemistry 1996; 11:43-51.

Sterckeman T., Douay F., Proix N., Fourier H., Vertical distribution of $\mathrm{Cd}, \mathrm{Pb}$ and $\mathrm{Zn}$ in soils near smelters in the North of France. Environmental Pollution 2000; 107:377-389. 